3-1-2008

\title{
Paternalism or Protection?: Federal Review of Tribal Economic Decisions in Indian Gaming
}

\author{
Kevin Washburn \\ University of New Mexico - School of Law \\ Barry W. Brandon \\ Philip N. Hogen
}

Vanya S. Hogen

Follow this and additional works at: https://digitalrepository.unm.edu/law_facultyscholarship

Part of the Indian and Aboriginal Law Commons

\section{Recommended Citation}

Kevin Washburn, Barry W. Brandon, Philip N. Hogen \& Vanya S. Hogen, Paternalism or Protection?: Federal Review of Tribal Economic Decisions in Indian Gaming, 12 Gaming Law Review and Economics 435 (2008).

Available at: https://digitalrepository.unm.edu/law_facultyscholarship/530

This Article is brought to you for free and open access by the UNM School of Law at UNM Digital Repository. It has been accepted for inclusion in Faculty Scholarship by an authorized administrator of UNM Digital Repository. For more information, please contact amywinter@unm.edu, Isloane@salud.unm.edu,sarahrk@unm.edu.

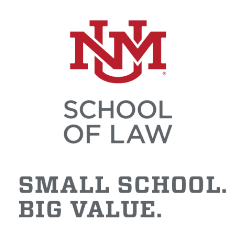

BIG VALUE. 


\title{
Paternalism or Protection?: Federal Review of Tribal Economic Decisions in Indian Gaming
}

\author{
Panel Discussion (edited transcript), Mar. 20, 2008, Harvard Law School
}

Introduction: In a recent Congressional hearing, Senator John McCain and Professor Kevin Washburn clashed about the role of the federal government in tribal economic decisions involving Indian gaming. Professor Washburn, who was struck by decades of incompetent governmental stewardship of tribal trust funds, showcased so painfully in the recent Cobell litigation, questioned the wisdom of the existing gaming regulatory structure in which federal officials at the National Indian Gaming Commission (NIGC) exercise oversight of tribal economic decisions involving tens of millions to hundreds of millions of dollars. Senator McCain sharply disagreed. Following his Congressional investigation of disgraced Republican lobbyist Jack Abramoff, McCain was even more certain that tribes needed federal protection from outsiders like Abramoff. McCain argued that the need for such protection justified close federal oversight of tribal economic decisions. The dilemma inherent in this exchange will haunt the relationship between the United States and Indian tribes in the post-Cobell (and postAbramoff) era. Which approach best serves Indian tribes?

The NIGC currently regulates tribal business relationships with outsiders in Indian gaming in two key contexts. First, under clear statutory direction and with strict legislative guidelines set forth in the Indian Gaming Regulatory Act (IGRA), the NIGC reviews tribal gaming management contracts and regulates the length, compensation, and other terms of such agreements. Perhaps because of the time, expense and opportunity cost in the lengthy NIGC review process, the Indian gaming industry has largely bypassed this regulatory scheme. Only approximately 55 gaming management contracts have been approved by the NIGC in the last 20 years, while more than 400 gaming operations have opened. In response to the marginalization of the management contract review process, the NIGC has recently begun to regulate tribal interactions with outsiders in a second context. On the basis of the IGRA's direction that Indian tribes retain the "sole proprietary interest" in Indian gaming operations, the NIGC has reviewed and expressed concern or declared illegal more than a hundred (non-management) contracts in which the outside contractor negotiated a percentage of gaming revenues for the term of the contract.

The NIGC's role in management contract review context and review under the "sole proprietary interest" standard raises important questions of federal Indian policy. In an era of tribal selfdetermination and self-governance, what is the justification for NIGC review of tribal economic decisions? Does the NIGC exercise a "trust responsibility" toward Indian tribes? What are the practical ramifications of having federal public servants reviewing tribal economic decisions worth tens or hundreds of millions of dollars? Are the costs of such review justified by the benefits? Is federal oversight useful for tribal transactions in which tribes have consulted with Wall Street investment banks and specialized legal counsel at sophisticated law firms? Are federal public servants competent to review the increasingly complex financial arrangements created in such transactions? Is the NIGC accountable for its decisions? What remedy ought to be available to tribes if the NIGC makes an error? If such review is necessary to protect tribes, on what basis should federal public servants disapprove such agreements?

A recent panel discussion at the Harvard Law School addressed these issues. The panel included Philip N. Hogen, Chairman of the National Indian Gaming Commission, Barry W. Brandon, Senior Vice President and General Counsel of Seneca Gaming Corporation (SGC), Vanya S. Hogen, a partner with Jacobson Buffalo, Magnuson, Anderson \& Hogen, of St. Paul, Minnesota, 


\section{DRAFT}

and moderator Kevin K. Washburn, the 2007-08 Oneida Indian Nation Visiting Professor at Harvard Law School.

Prof. Kevin K. Washburn: Chief Justice John Marshall first suggested that the United States has a trust responsibility to Indian tribes. Marshall did not call it a "trust responsibility" but he first described the relationship in two cases called Cherokee Nation v. Georgia and Worcester v. Georgia. Marshall likened Indian tribes to "wards" of the United States. He said that the United States is the "guardian" of the Indian tribes and this conception and other words in his opinions have served as the basis for the notion of a federal trust responsibility. Marshall was, to some degree, interpreting treaties and statutes, and even international law when he made these claims. When Marshall first expressed these ideas, he may have been attempting to explain where the federal Indian affairs power comes from. In more recent years, it has come to be seen at least partially as a limitation on federal power over Indian tribes. In other words, given that the federal government has a trust responsibility to Indian tribes there are certain things that it can do and ought to do in favor of Indian tribes and certain things that it may not do.

While the trust responsibility has long been an amorphous concept, it has really firmed up in a few areas in recent years because of extensive litigation. It is now recognized that the United States is a trustee and has fiduciary obligations to Indian tribes in certain circumstances. Perhaps the best illustration of that is Cobell $v$. Secretary of the Interior. When the federal government actually owns resources for a tribe and it exercises "pervasive control" over these resources, it is treated a lot like a private fiduciary and it has a clear trust responsibility to the Indian people for whom it holds these assets. The Cobell case, which was filed in 1996, has been up and down to the DC Circuit several times has been set for trial in June of this year, so we may get to see greater development of the scope of the trust responsibility. That case has generated of course a lot of headlines because first two Cabinet Secretaries and then a third and scores of attorneys at the Department of Justice and Interior were held in contempt of court by in Washington, D.C., during the litigation.

One of the most recent cases to reach the U.S. Supreme Court regarding the trust responsibility is Navajo Nation v. United States. In that case the Navajo Nation sued the United States for certain actions taken by Reagan-era Interior Secretary Donald Hodel. The Navajo Nation was negotiating with the Peabody Coal Company for a change in the royalty rate for an existing coal contract between the tribe and Peabody. In short, Peabody Coal Company was paying two percent of the gross proceeds of the coal to the tribe, a figure that was not consistent with market rates. The tribe was renegotiating its rate; it sought a rate of 20 percent, which was much more consistent with the market rates, and the tribe had obtained approval from the Bureau of Indian Affairs, an action that was appealed by Peabody Coal Company. The new higher rate was affirmed by higher officials, but Peabody Coal Company secretly approached Donald Hodel, who was then the Interior Secretary and said "You've got to help us out here." Secretary Hodel directed his staff to hold the appeal and wait, in an attempt to force the tribe to renegotiate with Peabody Coal Company.

Faced with more delay and a concern that it might lose the appeal, the tribe ultimately settled with Peabody Coal for a royalty rate of only 12 and a half percent. When the facts of Secretary Hodel's involvement came to light years later, the Navajo Nation brought an action and accused Interior of violating the trust responsibility by engaging in secretive ex parte communications with the Peabody Coal Company without the tribe's knowledge and allowing those communications to affect the administrative process. In examining the issue, the Supreme Court held that, under the federal statutes involved, the Department of the Interior's role was limited to oversight and approval of the final royalty rate. Given this limited role, the Supreme Court denied the Navajo Nation’s claim for \$600 million in damages. 


\section{DRAFT}

Taken together, the facts underlying Navajo Nation and Cobell have shaken tribes' confidence in the federal government and its ability to exercise a trust responsibility toward tribes. These cases raise three significant questions. First, is the federal government competent to serve in such a capacity? Second, is it better at making decisions for tribes than tribes would be themselves? And, third, if the federal government has the power and responsibility, can it be held accountable for properly exercising the power and meeting the responsibility?

Part of the fallout from Cobell is that the Department of Interior has begun to distance itself from any notion of a general trust responsibility. In decision-making documents, the Department of the Interior once embraced the trust responsibility, often using it as an alternative basis for a decision in many areas of Indian affairs. In more recent years, Interior has been much more guarded, rarely mentioning the trust responsibility.

Meanwhile, in the broader context of federal Indian policy, federal Indian affairs policy has moved far beyond the so-called trust responsibility. To most policy-makers, we live today in an era of "tribal self-determination" or "self-governance." Federal Indian policy, since at least 1970 when Richard Nixon issued his statement on Indian policy, has largely been focused on increasing tribal self-determination, tribal self-governance and tribal self-sufficiency. The general view is that government works best when it is tribes making key decisions about policy. This view is reflected in myriad federal laws. In light of tribal self-determination, what purpose does the trust responsibility continue to serve?

Indian gaming is an important arena in which to be having these discussions. Since the moves toward greater tribal self-determination have coincided with the booming Indian gaming industry, many tribes are extremely sophisticated about making their own decisions, and the question is whether those questions should continue to be subject to federal oversight?

I raised this issue in a hearing before Senator John McCain in 2005 when he was then Chairman of the Senate Indian Affairs Committee. I presented the idea that Cobell and Navajo Nation reflect a serious problem with federal oversight of tribal decision making, especially now that tribes are routinely represented in financial transactions by capable attorneys in Washington and New York and investment banks on Wall Street. In sum, the question is whether it is sensible to have general schedule federal bureaucrats in the GS-13 or GS-14 range looking over the shoulder of tribal leaders and their advisors. McCain responded by disagreeing sharply. ${ }^{1}$ Following his investigation of Jack Abramoff, in which several gaming tribes paid the lobbyist tens of millions of dollars, McCain saw a need for even more federal oversight.

With that as the introduction, I have asked Chairman Hogen to describe the nature of federal oversight offered by the NIGC as a prelude to discussing its utility.

Phillip N. Hogen: Greetings from the NIGC. Here in Massachusetts Indian gaming has been a hot topic and some news clips suggest that the IGRA is the law that started Indian gaming. Not true. Tribes were doing very nicely with the gaming business before 1988 when the Act was adopted, although Indian gaming has grown immensely since that time.

Indian gaming didn't start on account of IGRA. It is not a federal program, and that is the first thing that I think needs to be understood. When Congress adopted IGRA the issue really was not “Are Indians going to do gambling?” but "When they do it, who's going to regulate it?” or "How is it going to be regulated?" As a result, Congress defined class II gaming that tribes could do on their own, and class III gaming for which tribes needed a tribal-state compact. Congress also created the NIGC. The purpose for IGRA was promotion of economic development in Indian country.

\footnotetext{
${ }^{1}$ Hearing before the Committee on Indian Affairs, Oversight Hearing on the Regulation of Indian Gaming, United States Senate, 109th Congress, 1st Session S. Hrg. 109-50, Pt. 1 (April 27, 2005) at 27-28.
} 


\section{DRAFT}

Many, if not most, of the tribes were very economically depressed at the time. They needed resources to lift them out of poverty. They needed a tool and legalized gaming could serve as one of those tools. The other thing well-known at the time was that gambling was a very lucrative business. If gaming was going to spread, some special attention needed to be given to its regulation because, historically, while gambling has attracted some wholesome investors, it has also attracted some nefarious characters. Nevada was Exhibit A in that regard. Nevada learned the hard way with respect to how you need to regulate the gambling business, and so the question then became, "Well how can we accommodate the interface of the tribes with those that have the funding to develop the gaming enterprises?" One of the things that was probably obvious was that tribes who were very economically depressed were dealing with some pretty heavy hitters who bring the financing dollars. That was an imbalance there. We need to guard against that.

Now with respect to the framework for the regulation of gambling set up in IGRA Congress looked to principles of good gaming regulation. All gaming regulators, including those of us at the NIGC, do three main tasks: First, they address the "suitability" of those who are going to be engaged in gaming, including the managers and the blackjack dealers, and others. Everyone closely involved in the business needs to have a background investigation. Being able to participate as a licensee in the gambling business is viewed as a privilege, not a right. That is, you can be disqualified from a license for gambling based on your reputation or based on your associates. It doesn't take proof beyond a reasonable doubt that one committed a violation to deny them a license.

Second, gaming regulators insure that gaming is fair and honest. Is it fair to the players? Are the players going to cheat? Regulators must create safeguards to make sure that no misbehavior occurs and that every player understands the rules.

Third, regulators must watch the flow of the currency; they watch that quarter from the time it goes in the machine until it ends up in the bank account. Now, in jurisdictions like Nevada and New Jersey that is especially important because the State taxes those revenues and they want to make sure every quarter gets counted, because if it doesn't get counted they may not be getting their share of the revenue. In tribal gaming, at the end of the day, it is all governmental revenue. Thus, tribes have an incentive to be even more diligent as to the flow of revenues.

That is the general framework for regulation. In IGRA, Congress also identified management contracts. Congress knew there were developers, who knew about the gambling business, and tribes, who were, in most cases, new to this industry. Under this management contract review arrangement, the outside developer investor was not only reviewed and approved, but I think gained some incentives by this arrangement. However, some limitations were established, such that manager is not allowed take the lion's share of the revenue from the deal. In an approved management contract, the manager cannot take more than 30 percent of the net gaming revenue. This was designed to reflect a fair return on the substantial investment that would be required to set up these casinos or bingo halls. If a manager can justify a certain amount of risk, the NIGC can approve a fee of up to 40 percent, but, for the most part, no more than 30 percent of the revenues may go to the manager. Second, Congress set a limit of five years on a management contract. I think a reason for that arrangement was Congress hoped and expected that after learning how to do it, tribes could take over the management of the facility themselves. Indeed, that has proved to be the case often. In a number of cases, tribes bought out the developer sooner than that and started running the enterprise before the end of the term of the management contract. Congress also provided that the manager can justify it with extraordinary reasons, then the term could be beyond five years, up to seven years. Before these management contracts are considered valid, the Chairman of the NIGC will have to review and approve those 


\section{DRAFT}

contracts and make sure that they meet the stated standards. The NIGC also does a very thorough background investigation with respect to the management contractors, the investors, the principal officers, etc. And if this regulatory regime is not obeyed, that is, if a tribe enters into a management contract with a manager or developer, and they proceed without approval, that contract is void as a matter of law, unless and until it is approved by the Chairman of the NIGC. To police these requirements, the NIGC can take enforcement action, such as a "closure" order to close the facility, or impose a fine.

Now why is that arrangement important to understand? Not everything one would call a management contract necessarily is a management contract. And on the contrary, an agreement called a "consulting contract" or a "development contract," or "loan" might actually be a management contract. How does one know the difference? One way is to determine what right to manage the gaming activity does the contract grant to the outside party? If the outsider has the right to manage the gaming, then it is a management contract. And it must be reviewed and approved to be valid.

In the early days, a lot of agreements were signed that weren't labeled "management contracts" though, in fact, they probably were. At that point, the NIGC started "calling them in," ordering the parties to submit them to the NIGC. In a number of cases, the NIGC invalidated them. In addition to what that management contract must provide as to limits on the percentage revenues for the management fee and for the length of time, and for background investigations done, the management contract must also set a maximum figure for the recoupment of development costs. In other words, there is a limit as to how much the developer can get back on his investment. The parties must carefully detail the arrangement as to what the compensation to the manager will be. The rules also require the establishment and maintenance of satisfactory accounting systems and procedures.

The NIGC must verify that all these rules are met. In addition, IGRA mandates: "The Chairman shall not approve any contract if the Chairman determines that a trustee exercising the skill and diligence that a trustee is commonly held to would not approve the contract." Well what does that mean? That is the question.

Professor Washburn explained the origins of the trust relationship that exists between the United States and Indians or Indian Tribes. For those of you taking Trust and Estates class in law school, you know that trust has three elements: a trustee, a beneficiary, and a corpus of the trust. Well, in the context of a management contract between a tribe and a manager, you don't have that classic arrangement. Certainly, you have a business arrangement and you have a responsibility imposed on the bureaucrat who reviews and approves the management contract, but it is not classically a trust arrangement.

In terms of the development of this trust responsibility that Justice Marshall developed in the early cases, the Non-Intercourse Acts, which preceded those cases, said that an ordinary person cannot contract with a Tribe unless the federal trustee participates. The land of Indian tribes was deemed to be federal land in trust. And then, in 1871, Section 81 of Title 25 United States Code was enacted. It said “All contracts relative to Indian lands must be approved by the Secretary of the Interior or else they are not valid.” Why did Congress do that? Well, there had been a series of swindles and other nefarious kinds of activities where tribes and in many cases individual Indians had been defrauded or taken advantage of by members of the dominant society who knew a whole lot more about mortgages and such. Congress enacted Section 81 and it covered every contract relative to Indian lands. Therein was the problem. What does "relative to Indian lands" mean? And in the cases, interpretations of Section 81 were all over the map.

Moreover, if you were an attorney representing a Tribe, you had to get your contract approved by the BIA or by the Secretary of the Interior's representative. When I was representing Tribes, I would send my attorney's contract to what we called in those days the 


\section{DRAFT}

“area office.” I could not work for the tribe unless I obtained that approval. When we submitted our bill, we had to have approval from the area office for the legal services that we rendered. The instances that led up to the enactment of Section 81 in 1871 were arrangements where contingency arrangements were set up by attorneys. In a lot of cases, former military officials that had been Indian Agents and attorneys that represented tribes, ripped off the tribes and ripped off the federal government at the same time. That contributed to the enactment of the review provision for attorney contracts. That led to this proposition: if you are an attorney and you are going to have a contract with a Tribe, it must have the trustee's approval, that is, the Secretary's approval. That was the law of the land in 1988 when IGRA was enacted, and Congress, I think, had the wisdom to know gambling is a specialized kind of situation.

Congress essentially said, "We don't believe that the Secretary of the Interior has the experience or the insight with gambling transactions to handle these functions, so we are going to task this newly created agency, the NIGC, to fulfill that role." So the NIGC now does what the Secretary was once doing with respect to these contracts with Tribes relating to gaming, only we have much greater specificity with respect to the contracts that fall under this approval requirement.

In the meantime, in the year 2000, shortly after IGRA was passed, Congress changed Section 81. They realized that this "relative to Indian lands" principle was inhibiting the expedient transaction of business by these Tribes that were now running programs under the selfdetermination policies. So Congress pared Section 81 back a great deal. Now, if contracts encumber Indian lands, then they have to have the approval of the Secretary of the Interior, but that's a whole different approach from before 2000. Oddly enough, however, Congress didn't address the task the NIGC was given under IGRA at that time, so we still have to review and approve all of the management contracts.

One of the challenges is how to identify a management contract as opposed to a development agreement, loan, or consulting agreement. So the NIGC issued a bulletin. We have requested of all Tribes involved in gaming, "please send us your contract with a developer, with a lender, et cetera, so we can look at it to decide if it needs approval, because we don't want to find ourselves having to come knock on your door years later and say 'by the way, that is a management contract. We have to declare it void." Maybe they'll get the money back they paid under that contract, but that's not a good arrangement. So, on a routine basis, the NIGC reviews contracts from Tribes. They are not required by the law or by regulations to seek review, but most of them find their way to us and we look at them. In many cases we say "This consulting agreement is a management contract, but if you will change this or that, you can take it out of that category," and that very often happens. That is, they modify the arrangement. In most cases -- we are wearing that trustee hat, we're trying to look at it from the trustee's perspective -- the Tribe gets a better deal as a result of our involvement.

So, it's from that frame of reference that we are doing what we are doing. Sure, it is problematic to have a hundred million dollar deal reviewed by a GS-13 sitting there in Washington. You know, Bear Stearns -- or maybe that's not a good example [audience laughter] -- but somebody maybe, you know, with a little more moxy should be looking at those agreements, but that's our task; that's what we are assigned -- and we are getting a lot better at it.

I drafted the management contract for the Oglala Sioux Tribe with Turnkey Gaming. If you want amusement, look up the Turnkey cases; those contracts have been litigated through the courts. ${ }^{2}$ I tried to get that contract approved by the NIGC when I was out in Rapid City. We

\footnotetext{
${ }^{2}$ Ed. note: See Turn Key Gaming, Inc. v. Oglala Sioux Tribe, 313 F.3d 1087 (8th Cir. 2002); U.S. ex rel. Steele v. Turn Key Gaming, Inc., 260 F.3d 971 (8th Cir. 2001); Turn Key Gaming, Inc. v. Oglala Sioux Tribe, 164 F.3d 1080
} 


\section{DRAFT}

wanted to get the casino open by the first of October because the National Indian Rodeo National Finals were starting on that date, but NIGC wouldn't approve that contract and so we ended up with an employment contract. A year later I was appointed to the NIGC. A week after that, the NIGC finally approved the contract just as I had written it, a year and a half earlier, but by then, the transaction had fallen apart. It did not produce a successful operation.

In the meantime the Tribe fired me because I couldn't get the contract approved, and they actually fired me on the tribal radio station. KILI broadcasted tribal proceedings, so my firing was broadcast over the radio. One of the things I learned from that experience, and we learn every day, is that these commercial transactions are fragile, both politically and financially.

Typically, they will start like this: some developer will come to a member of the tribe and say "Boy, have we got a deal for you. We know how to run these casinos and we can make a ton of money. If you'll get in with us, then this will work out well," and then there is a person at the tribal level who's a champion of Company A. Well, he or she may have longstanding political enemies who said "if that person thinks it's a good idea, I know it's a bad idea." In short, the tribal politics begin. And, of course, the people with the money are not going to wait forever. They know every day that the casino door is not open is costing them money. And it is costing the tribe money, and they need to go forward. So there is a great incentive on everyone's part to try and get through the review or approval process quickly. But it is a complicated process and we are a lot better at this today than we were back in 1995 or 1993 when I sent that Oglala Sioux contract to NIGC. We have now approved 55 management contracts. We've reviewed, I think, 265 of them, so obviously a lot of them didn't last through the process. In some cases, it was because it wasn't a good deal or it wouldn't work. In some cases, the tribe, after more review, said, "let's do it ourselves." We have reviewed a whole lot more than that of what we call "R contracts"; that is "are they management contracts"? We have reviewed more than 400 such agreements.

Our review is also governed by one of the things that IGRA says, which is "The Tribe shall have the sole proprietary interest in the gaming operation." Well, what does that mean? A sole proprietary interest; that's not a term used very often in business or law. But we can figure it out. We all know who the proprietor is - that is the owner, and so the Tribe must be the sole owner. But how much of an interest, how much control can an investor have before he becomes disqualified by acquiring a proprietary interest such that the Tribe can no longer be said to have the sole proprietary interest? So that's a challenge to us. Are we properly applying that standard? And I think we'll hear more as the morning wears on about how not everybody has agreed with the decisions that we've made or the guidance that we've given in that connection. We are saying we consult with Indian Tribes on a government to government basis, basically as often as we can. Ordinarily those consultations occur when we go to a regional Tribal meeting like the meeting of the United South and Eastern Tribes (USET). When they have their annual meetings, we will invite all of the Tribes in that organization to come consult with us and we will meet for a time with each of the individual tribes, and we have a list of things we talk about during those consultations, and one of the things currently on our list is our implementation of the "sole proprietary interest" provisions.

We are thinking about drafting guidance that will more clearly define what that term means so we can, first, perform our statutory responsibility from the point of view of a trustee, but second, not stand in the way of people doing business.” Keep in mind that we have nearly 500 Tribes engaged in gaming. They're as diverse as their cultures: fisherman, hunters, gatherers -- and their business experience is diverse too. Some know way more than the NIGC

(8th Cir. 1999); Turn Key Gaming, Inc. v. Oglala Sioux Tribe, 164 F.3d 1092 (8th Cir. 1999); U.S. ex rel. Steele v. Turn Key Gaming, Inc., 135 F.3d 1249 (1998). 


\section{DRAFT}

will ever know about running a business, and some are not so sophisticated; some have had it tough and there just hasn't been any economic opportunity for them. So one size doesn't always fit all in the way we approach these things, but we want to be part of the solution; we don't want to be part of the problem.

Indian gaming is the best economic development tool that ever came to Indian country. It hasn't worked every place by any means. We'll never get rich at Pine Ridge; we've got too many Indians and not enough customers, so to speak. But it's provided employment there that we didn't have. In this business, it is "market, market, market." If you are located in the right place, you can generate tons of dollars. And so it is not going to solve all of the problems, but it has worked in large part because the Tribes are able to do it themselves. Our job is not to get in their way but yet fulfill that task with which we've been statutorily assigned. We wear that trustee's hat and make some of the decisions. So that's generally what the NIGC does there in this connection, and why we do it, and I look forward to the discussion.

Prof. Kevin K. Washburn: Now Judge and Attorney Hogen, can you give the private litigant's or the private person's perspective on this issue?

Vanya S. Hogen: Sure. The management contract review process is an extraordinarily timeconsuming process. I haven't run one through from start to finish in a few years, but I think that it still is taking between one and two years. From the time that you have your contract signed with the Tribe and the management contractor, you submit it to the NIGC, you're looking at one to two years to get it approved, which is problematic because anybody who's working on one of these deals is in a hurry. The Tribe wants to get the casino up and running as soon as possible. The management contractor wants to get the casino up and running as soon as possible. And, so over the years, management contractors and Tribes have tried to figure out "How can we get a casino up and running without a management contract, because we don't want to add two years to the process." And, of course, sometimes it is even more than two years because the NIGC approval process also can trigger the National Environmental Policy Act, NEPA. So then you have to do an environmental review of the casino construction -- and there are obviously good things about this -- but in giving the public an opportunity to comment, it gives anti-casino groups an opportunity to just pick apart any little thing they can find in the environmental review process and drag the casino construction out even longer.

So, Tribes and contractors strive for alternative arrangements. As the Chairman said, a lot of times they seek an arrangement where the outside company is giving advice to the Tribe, but not actually running the Tribe's casino. Because the NIGC did issue some guidance back in 1993 about the difference between a management contract and a consulting agreement, the industry became adept at figuring out where that line was. There are still ambiguities about it when the company is providing advice. For example, when does that activity turn into management? But the industry generally learned how to draft a development agreement that stopped short of management.

I tend to represent developers in these kinds of transactions. If my clients are going to develop a casino for a Tribe, that is, do all the work that's necessary to get that casino to opening day, and then turn the keys over to the Tribe and have no further involvement with the casino after it opens, that cannot be considered a management contract. Such a developer simply is not running a casino; they are only exercising control over the development process when there is no casino business. So, in the last seven years or so, a number of new casinos have been developed in this turn-key manner. Often, there is an outside developer, but there is not an outside management contractor. As the Chairman said, I think there have been 55 or so management 


\section{DRAFT}

contracts that have been approved, but there are vastly more casinos. Over 200 Tribes are gaming now, so the vast majority of these operations don't involve management contracts.

This caused some concern. The NIGC, I think, was worried that there are all these casinos going up out there under contracts that were not being scrutinized by the NIGC. There were a couple of transactions that earned a lot of scrutiny by the media because they were lucrative to outside contractors. The NIGC started to wonder how it could reach those deals. The NIGC started to look at the section that nobody previously noticed much in IGRA. It says "The Tribe has to have a sole proprietary interest in the casino."

The industry knew that this provision there, but we thought that it meant only that the Tribe must own the facility. If so, the Tribe maintains its "sole proprietary interest." But starting in about 2000 or 2001 the NIGC started sending out letters on some of these controversial deals that made the newspapers, where outside developers were making sometimes billions of dollars on these casino deals. The NIGC sent letters saying, "We think that these transactions may be problematic because the outside developer is getting so much money that they may be taking a proprietary interest in the casino, that somehow that fee is so large that they are taking an ownership interest in the casino.” That could well be true, and I may get asked later on about what the standards should be for an outside developer.

But what I wanted to focus on is about the procedural problems with the sole proprietary interest analysis and why it has not worked very well. As I say, it started back in 2000 or 2001; I think maybe even Mr. Brandon and Professor Washburn here may have signed a couple of those letters. At that time, no one knew anything about this. The NIGC didn't issue a bulletin. These letters only went out to the folks who were involved in deals being reviewed by the NIGC. Most of us were still working on transactions thinking, "we only have to make sure that our contracts are not management contracts" and we knew what the rules were with respect to management. The NIGC then gradually started sending out more and more of these letters. The NIGC would make statements such as "The fee to the outside contractor is too high." Or, "The outside contractor's risk does not justify this high fee, so there is a proprietary interest violation.” Soon, word began to spread among those of us who practice in the field. We began to try to structure our deals to make sure that we could meet the proprietary interest standard, but the problem was, because these letters just go out to the particular people involved in these deals, it was really difficult to know what the standard actually was. How high can a fee be before it produces a proprietary interest violation?

We know that in IGRA management contractors can get up to 40 percent of net revenues for up to seven years in some circumstances, and apparently that's not a proprietary interest violation, but some of these letters that were coming out from the NIGC were saying that fees that were far lower than that were giving developers a proprietary interest in the casino. This suggests that there are several problems with the way this regime has developed. First, the NIGC started doing this without giving notice to anyone. This language about "sole proprietary interest" had been in the statute since 1988, since IGRA was first enacted, and the NIGC had not said anything about it or taken any enforcement actions about it. Even today, now that the NIGC has been using proprietary interest analysis for a few years, there is still no bulletin and no regulation.

The only way that a practitioner can try to determine what is or what isn't a proprietary interest problem is to try to obtain the NIGC letters. Unless you are involved in a transaction and receive one of these letters or obtain them from a colleague in another transaction, you must file a Freedom of Information Act request with the NIGC. Well, that causes problems as well. For one thing, it takes at least six weeks and sometimes several months to get a response. Moreover, the terms are redacted. As a result, you can learn the identity of the parties and learn a little about the contract under review, but the financial terms are redacted. As a result, it is impossible 


\section{DRAFT}

to determine what percentage of revenue the developer was to receive, and why that contract was problematic. As a practitioner trying to advise my clients on gaming transactions, it is very difficult to provide advice because you don't know what those standards are.

The other problem with those letters is that, even if the financial terms are known, the NIGC does not necessarily tell you how to fix the contract. In my experience, they will tell you, "This deal is not good," but not much more. For example, they might say " 14 percent of gross revenues for five years is too much," but they don't give you an acceptable level of compensation. Thus, you are forced to go back and renegotiate the deal and reach a new agreement and then resubmit the contract to the NIGC. It can take a long time for the NIGC to get back to you and say whether your new number is okay or not. And if it is not satisfactory, they, again, don't give you an acceptable number. Renegotiation is not only expensive; it really tests the relationship between the developer and the Tribe. It puts the developer in a horrible negotiating position when you think you've negotiated a good deal. When the NIGC says "No, that's not a good deal," all you know is that you must agree to a lower fee. The Tribe has all the leverage in that situation. This is very difficult as a practitioner.

Another problem with the letters is that they are not always based in reality in terms of the market. The NIGC might suggest that the developer is not providing enough services to justify this kind of a fee. And it might assert that a typical developer's fee is actually only "X." Well, I received one of those letters about a deal a couple years ago and it was just completely wrong. The numbers that the NIGC was saying was typical for the market did not agree with my experience or my client's experience in the market. But because this is such an informal process, there was no good way for us to get that information to the NIGC or to even be heard.

And that brings me to the last point that I want to make. The process of obtaining an advisory opinion letter is really stacked against the developer. The NIGC views itself, probably rightly so, as having some kind of trust responsibility to the Tribes, but they're also regulating the Tribes, so they feel like they are looking out for the Tribe in these transactions to make sure the Tribe isn't getting ripped off. But the NIGC is also supposed to be making these regulatory decisions, and the way the problem manifests itself is that if you are representing a Tribe and you want to have a meeting with one of the Commissioners or the General Counsel at the NIGC, it is extremely easy to get that meeting. You call the NIGC and say "I've got the Tribal Chairman. I want to come to Washington and talk to you about this deal.” In such circumstances, one can usually get in the doors of the NIGC in very quickly. If you're representing a management contractor or developer and you call the NIGC, they will not meet with you unless you can get the Tribe in there with you. If the Tribe sees an opportunity for a better deal, the Tribe may not be very anxious to try to support your client justifying the fee. In that respect, it is not a fair process; one party to the transaction has much greater access to the regulatory agency than the other side.

The last problem is that some of the parties essentially ignore these letters. They just go ahead and do the deal, even though the NIGC has issued a negative advisory opinion. In a case that I worked on last year where Professor Washburn was an expert witness, I represented the casino developer. There was also a gaming machine vending company who had a series of contracts with this Tribe to provide some financing on the casino and a lot of the machines. We submitted all the contracts to the NIGC at once, including the development agreement with my client and the loan agreement and machine lease agreement with the gaming machine vending company. The NIGC sent a letter back to my client saying "We think your development agreement gives you a proprietary interest." The NIGC sent essentially the same letter to the gaming machine vendor. When my client received the letter, we started working on how to address the regulatory agency's concerns. So we contacted the agency and worked hard to figure out exactly how to change the contract such that it would not violate the NIGC's view of the 


\section{DRAFT}

proprietary interest standard. As a result, we ended up in litigation and arbitration with the tribe before the tribal court, the state court, and the federal court. It took forever to resolve. Meanwhile, the gaming machine vendor ignored the letter and just kept operating under those contracts. As far as I know, the machine vendor is still is operating under those contracts, and never ended up in litigation with the tribe. The tribe just kept paying them, and there has been no consequence. That is not a very good regulatory scheme, in my view, if trying to be conscientious actually gets you in more trouble than if you just ignore what the agency has to say.

Barry W. Brandon: I'm going to take a different tack here. Professor Washburn raised a Senate hearing in which Senator John McCain made reference to the \$82 million that Tribes paid to Jack Abramoff. In my opinion, Indian gaming and Jack Abramoff are not related. A lot of this money came from gaming Tribes, but what Jack Abramoff did with respect to basically going in and ripping Tribes off and bilking them and doing all of those types of things was just criminal activity that, you know, he used to prey upon Indian Tribes who either lacked the sophistication or heard and drank the Kool-Aid that Abramoff was offering. For those of you who followed it, a lot of it involved corrupt individuals within the Tribe. Basically what Abramoff was promising them was this: "You hire me and pay me money, and I'll make sure that you get elected in perpetuity. You'll always be in power at this Tribe," and that's where a lot of this money was going, and so it's interesting that he would note that, but again I think so much with Indian gaming is getting back to the facts, because notwithstanding the comments of Senator McCain, I don't think anything under IGRA would have prevented that from happening. These were individual tribes making individual decisions based upon governmental actions, and a lot of those Tribes had a purge after that. A lot of those individuals who made those decisions and who are responsible are no longer in power, and the processes within the Tribes worked to flush it out.

Furthermore, there is another issue often addressed in the media. It was on the cover of Time Magazine, in articles in the Boston Globe, and in numerous other papers. The Buffalo News ran a bunch of stories about the Seneca Nation, for whom I work, about the fact that nonIndians are earning money from Indian gaming and acting as though this was a scoop. So, one needs to understand the process by which IGRA triggers various requirements. First of all, on its face IGRA contemplates that non-Indians are going to make substantial money from Indian gaming operations. If you have a management contract for 30 percent of net revenues, that is a boat load of money that Congress recognized that a manager would obtain in an Indian gaming deal. Even if the Tribe does not choose the management contract route, if it simply finds its own developer and financing necessary to do a deal, other non-Indian entities are going to be taking a lot of money out of these deals. That is how business works. Indian gaming is no different than a lot of other economic ventures -- and especially high risk ventures. A lot of the investors are venture capitalists. They are risk takers.

In the early days, some of the transactions that are now famous, whether it was Foxwoods or Mohegan or even the Seneca Nation, it is not surprising how much Tribes paid to get into the industry. You are talking about people who had no significant financial capital. They had no way to finance building a casino. The industry was unproven; there were (and are) constant lawsuits and constant rumors about IGRA being changed, and many other factors.

Notwithstanding the fact that casinos could be pretty profitable in the early days and even depending on where you are in the country, they are highly risky ventures before they become operational, and the risk was reflected in the price of a lot of the deals.

The fact that non-Indians are actually making money off of these deals shouldn't be surprising. Let's talk about why that happens. Case in point: I will use the tribe that I work with 


\section{DRAFT}

today. I was hired back in 2001 to help the Seneca Nation of Indians negotiate a gaming compact with the State of New York. They successfully negotiated a compact providing for three casinos in Western New York; two of them were off the reservation: one in downtown Buffalo and one in Niagara Falls. We endeavored to get the compact signed by the State of New York, then sought final approval from the Secretary of the Interior.

I can’t resist making an editorial comment. Welcome to the world of Indian affairs and practicing Indian law. We had a compact that was negotiated over 18 months across the table by the State of New York through the Governor's office that was then subjected to the Assembly of the State of New York where it was approved. It was then put in front of a Tribal referendum before the Seneca Nation of Indians to which the majority vote said that they wanted to accept it. It had gone through numerous approvals, including the local municipalities; Buffalo and Niagara Falls had signed on and said that they were in favor of this compact. And after all of that and having these two governments sit down and reach this agreement, whether or not this deal goes forward is subject to one person in Washington, D.C., who could say no to it, even though every other governmental entity was in agreement. So we waited 45 days for our approval letter.

Well, at that time, we had already been talking to banks. We'd been to Wall Street and had been talking to all the big banks: Merrill Lynch, Wells Fargo, Bank of America, Deutsche Bank. All of those had come in and met with the Board of Directors of the gaming operation and the Tribal Council for the Seneca Nation. Every one of them was interested in the deal. Each said, “This is going to be great. It's going to be very successful. We wish you all the luck, but come talk to us at the beginning of the year after your compact gets approved, because there's no way we can loan you that money until then.”

Consider what happened next. Our compact provided that we would take over the Niagara Falls Convention Center. The state essentially gave us the Convention Center for one dollar. That was where we were going to establish the first casino, and as we began to hire people and engineers to develop the plans, we learned that there were some serious problems with the roof on the building. And the fact of the matter was that if we didn't get the casino opened in the fall, then it would not open until probably the next August or September because we needed a protective overlay on the roof, and that can only be done in temperatures 40 degrees and above. We looked at the Almanac, and in Niagara Falls, New York, we were running out of time. It was either right then or wait until next year. So, this really put the pressure on us to get financing in place. Well again, none of the banks wanted to talk with us.

Our CEO had a relationship with an investor who had also done other financial transactions with Tribes. He came in, assessed it, and concluded, “This is highly risky. You do not even have an approved compact yet." But then he said, "I am willing to take that risk, but here is what I want. I want a percentage of your revenues over a period of time to compensate me for this risky investment.” The deal was structured so that everything that was at risk up until the time the compact approved was his risk. If the compact failed to gain approval, he was going to lose about -- I think at that time it was about \$15 million. We were about to begin spending half a million dollars a day. In light of all the details that Chairman Hogen mentioned, the Tribal politics, the state politics, politics in DC, it was clear to us that we needed to move forward. We told the Tribe that we had to get the construction going because it was a house of cards and we might well lose the whole endeavor if construction did not begin then.

At some point, we performed the financial analysis and showed the Tribe how much revenue they were going to earn on this casino every day that it was open. We did the math and the projections and said "If you open on December 31, which was the target date, versus September 1, here's how much money you're going to leave on the table.” They then sat down in earnest with a venture capitalist who wanted a long-term interest in the deal that was going to spread money over a long period of time. We said "No, there is no way we're going to give you 


\section{DRAFT}

an interest in this." So, basically, what happened was that we squeezed essentially what is really an equity deal into a term loan, which shot the interest rate up through the roof. So, the media reported that we were paying this investor 29 percent interest, which was true, but when you peeled it back and understood the issues, it made sense. The investor would make a lot of money, but up until the time that we signed those documents, the only person at risk was him. I mean, the Seneca Nation was legally going to be able to walk away scot-free from this deal.

The tribe faced this decision will full information and with the advice of sophisticated legal and financial counsel. The Tribal Council carefully considered the risks and benefits and made the decision. The President of the Nation at the time said "Look, this doesn't bother me. When I started my business on the Reservation, no one would loan me money, and the way I got money is I went out and I signed up for as many credit cards as I could get, and some of those carried interest rates of 25 percent and I max'ed out on the cash advances on all of them. That's how I got my business going, so I know what it's like to be an Indian, I know what it's like not to have money, and I know what it is to take a risk.” Thank goodness the Secretary eventually approved the compact and everything worked out. But, as the dust settled, the media suggested that the tribe had been ripped off. Well, if the tribe didn't think it had been ripped off. The bottom line was that this extraordinary loan allowed the tribe to open a facility which was making a million dollars a day.

That agreement actually went to the NIGC and the NIGC actually kicked it back for some corrections. It was not on the sole proprietary interest. It was the default provisions in the contract. In the event of a default, the investor was going to have certain rights vis-à-vis the property, and that's what the NIGC focused on and said "Look, we think that you're giving up some control in the event of default."

Fortunately, that did not cause a problem. We went back to the table and cleaned up certain provisions. And it did work out. But time was on our side. Had that happened earlier on, I probably wouldn't be sitting here today as the General Counsel of the Seneca Gaming Corporation. It would have had a huge impact. Obviously we would have lost funding that was going to be necessary, so timing on that in terms of the delay from the NIGC actually was our ally from a Tribal standpoint.

The other example I wanted to mention actually happened when I was at the NIGC. Another one that I was involved with, just to give you some ideas -- and this was early on and it involved a tribe from Connecticut in which they were trying to buy out early the management contractor with whom they had signed a deal. It ended up on my desk as the General Counsel because there was an argument from within the agency as to whether or not the buyout agreement constituted a management contract or not. The management contract people were looking at it; the legal staff was looking at it. For the life of me, I could not figure out how the Tribe, by attempting to distance themselves from the management company, was somehow entering a management contract. The tribe was basically asking the management contractor to leave. I did not think that such an agreement, a buy-out, could constitute a management contract, even though there were some that felt it was because the buyout appeared on its face to be very lucrative. It provided lots of money to this person or this company over a long period of time.

Again, the Tribe was very sophisticated and knew what it was doing. It had high priced lawyers; it had very good accountants; and at that point, we thought the best thing to do was just to bring the Tribe in and talk with them about it and tell them that there were some concerns with respect to some of the provisions on the buyout. We brought them in and asked them about it They said, "Look, we understand. We have talked about it over and over again. We want to run our own facility. We realize it's a high price to pay but we're willing to pay it." And that was the collective wisdom from the Tribal Council. Our assumption was that these were the elected leaders of this Tribe and they were making a business decision. At that point, we decided not to 


\section{DRAFT}

substitute our own business judgment for the Tribe's. I signed a letter that said "This is not a management contract, and therefore the NIGC has no jurisdiction over this.”

That letter created a lot of controversy. The Boston Globe insinuated that there was something wrong with the decision. The articles reflected little understanding of the financial, legal and political issue involved in such a deal in Indian country.

Going back to the Seneca Nation, we also ended up getting out of that deal early. We got out after three years instead of five, and that was all brought to bear from political pressures within the Tribe and it was a little bit awkward because the Tribe prides itself on its honoring of treaties and agreements that it enters, but the political pressures were so intense there -- a lot from the misinformation that was developing -- that the Tribe directed us to go back to the investor and essentially ask for an early out.

And, contrary to the way that the press would portray these people, the investor in that instance did something that he didn't have to do. He agreed to an early out, which saved the Tribe about \$20 million, and that was \$20 million that he didn't have to give up. Part of that outcome was just because of an agreement and a face-to-face meeting between the Tribal leadership and him. He did it because he wanted to preserve a relationship. It was also an integrity thing with him, because he realized that there were numerous people from within the Tribe that disagreed with the loan in the first instance. Needless to say, he made a lot of money. But such is the way. Venture capitalists who take those type of risks either lose all or make big money. So these issues are not always so simple.

Now, I want to address one matter about the proprietary interest issue. It is being used against Tribes in that it is a risk factor that goes into borrowing money. When we have talked with investment banks and others, they are very careful to ask about it. They are aware that these letters do come out and they can be problematic, and so they have that impact on lending institutions. Banks look for anything that might drive up the cost of doing business. So, in that instance, it can hurt Tribes with respect to creating a risk factor. The lender can then say, “That's going to cost you another half a point," which, on a \$500 million deal, is a lot of money.

I know that when we first were called to represent the Seneca Nation those developers were swimming all around, because they wanted to do a deal with them, and luckily through the process and through really working with the Tribal Council, the Tribe's learning curve was really steep and they became very smart real quick and started asking all the right questions of these developers in terms of what are they going to get out of it, and "What is the market rate?" and "What should we be paying?" and "Do we have to hire a management company?" So as a result of that, ultimately they ended up hiring professionals; not a management company, but just hiring individuals to come in and help them run their facility.

Prof. Kevin K. Washburn: Let me ask a question. The NIGC doesn't have a responsibility to developers. If it has a trust responsibility to Indian Tribes, why should we care about developers? Are there any practical ramifications for Tribes if the NIGC is being unfair to developers?

Vanya S. Hogen: Well, as Mr. Brandon made pretty clear, you can't get these deals done without outside help. The developers usually provide at least some of the financing and all of the know-how in terms of getting a casino up and running.

I will be interested to hear, those of you who worked at the NIGC, your perspective on the responsibility to Tribes and how that manifests itself when you're looking at these contracts. These transactions take a long time to put together from the time the Tribe decides to accept the initial pitch of a developer to the time that they break ground on the casino and get it open. This 


\section{DRAFT}

can often be three to five years, and that is a long time for the parties to have to keep the deal hanging together with all these political pressures coming up.

For the NIGC to keep a dialogue going only with the Tribe and not the developer makes it harder for the deals to hold together long enough to actually get the casinos up and running. The NIGC should pay attention to developers because they are integral to the process. By not paying them attention it often can lead them to walk away from the deal. I can't tell you how many developers or lenders I've talked to in the last couple years since this whole proprietary interest issue has really come to the fore who said "I never want to do another deal in Indian Country again. We don't know what the rules are.”

Prof. Kevin K. Washburn: Chairman Hogen, if this has negative ramifications for Indian Tribes because developers are walking away, deciding that they don't want to do business with Indian Tribes, what does that mean? Presumably a smaller pool of people willing to do business with Indian Tribes is bad. So, if we think that a higher number of potential partners will make the environment more competitive and give Tribes more options, that is not happening. This may drive up the cost for Tribes.

Philip N. Hogen: Well, you did a good job in your opening remarks giving an overview of the trust relationship and its development and so forth, and you referenced the Navajo case, the coal royalty case, and there was an example where the trustee was talking to the developer, talking to the coal company when they should have been talking to, if not just to the Tribes, certainly to the Tribe as well. We who wear the trustee's hat probably are a little gun shy when it comes to talking to somebody besides the Tribes in that context. But, the developers -- that's where the money is. The development won't work unless you get the right people to the table, so we ought not be scaring them off or discouraging them. Still, we have to reconcile that interest in developing resources for tribes with our obligation to keep faith with our ward, so to speak, the Tribes. So, it is a delicate balance.

Prof. Kevin K. Washburn: Mr. Brandon, you expressed frustrations. The story you told is basically this: It is very difficult to get a gaming business going. Many different stars must align. As with any business, you have to have customers and a viable market. But, in Indian Country, in addition to the regular business risks that every business faces, there are many additional legal risks. Who knows if the Secretary's going to approve the compact? Who knows if the NIGC is going to approve the management contract? Who knows if the NIGC will conclude that an agreement violates the sole proprietary interest principle?

My experience with gaming suggests that, for the casino operation anyway, gaming is a license to print money. It is not an inherently risky operation if you are in a market that has no competition, or little competition. So there is very little business risk. The entire amount of risk is caused by the involvement of the federal government. In other words, we have artificially created risk where there it would not have existed. Does the trust responsibility actually harm Tribes more than it helps Tribes in this context? Please comment.

Barry W. Brandon: Well, IGRA was enacted to provide an economic development tool for Tribes, but inherent within the process that it creates is that it is very, very difficult to get those developments done. The fact that you need a compact approved by the Secretary of the Interior based upon the oversight and trust responsibility to make sure that the Tribe is not getting ripped off makes it difficult. I understand the role. But when you look the risk factors it is striking. We have sought some public financing and when you go through our offering memorandums and other disclosures and you look at the risk factors and count up how many of them really do apply 


\section{DRAFT}

to what it is that you're talking about, which is compact approval, amendments to IGRA, NIGC regulations, all these other things that are external to things that the Tribe doesn't have any control over, that could potentially impact the business, those are significant.

Prof. Kevin K. Washburn: Those are all legal/regulatory hurdles.

Barry W. Brandon: They are regulatory hurdles, and you are right. Gaming is very lucrative. That is why somebody is willing to invest $\$ 200$ million for a license to open a gaming operation. It is lucrative, but there are lots of risks. Once you get open and get operational, the risks tend to diminish but getting through that gate in the first instance is the most difficult challenge.

Philip N. Hogen: A reason Indian gaming has been as successful as it has throughout the country is that there is not much competition out there. If you go to California, for example, the only place you can go to a real casino is on an Indian Reservation. This is true in every state but the handful of states that have legalized casino gambling. One reason it unfolded that way, I think, is because there was integrity under the regulatory structure set up in IGRA. There were a lot of checks and balances, if you will. There are many who say, "We must not amend IGRA, not because there aren't some things wrong with it, but because if we try to amend it somebody will follow it up with other amendments and it will not work as well as it has worked." I am not one of those. By now, 20 years have passed and it is time to take a look at it, and I think that there are some things that could be fixed. But if we take out these checks and balances, such as the role of NIGC to review whether or not there is or isn't a proprietary interest, you will find that this doesn't really have anything to do with how big a market share Tribes will get down the road. Once you tinker with that, you might jeopardize the success that the industry has enjoyed. In short, the structure with all its flaws has worked, but certainly it is not perfect.

Philip N. Hogen: Let me ask a question of Judge Hogen here. Is "sole proprietary interest" a viable concept? If we were starting over or if we were going to write it differently, is there better terminology to employ or a better concept? There is not a lot in the legislative history that tells us really what they were thinking about.

Vanya S. Hogen: I think it probably is a viable concept. Pure ownership is one standard. The Tribe does have to legally be the owner, but I think the other touchstone in the research I have done -- because I've written a lot of briefs about this now - is that there has to be some element of control. If you literally have a developer who is offering a turnkey operation, who wants to get the doors open to the casino and leave, and the developer is not anywhere near the Tribal operation, then getting a fee by itself cannot constitute a proprietary interest in the casino. There has to be an element of control. And I guess my main concern as a practitioner in this area is not so much that the NIGC needs to back off and not enforce the sole proprietary interest theory or the Tribes have to do that, but that someone should actually publicly say "This is what it means." People must be on notice so that they don't have two casinos up and running and then get a letter from the NIGC saying "Oops, we think you have a proprietary interest problem.” And then there is another interesting issue here. For management contracts, if you enter into a contract that the NIGC later says is a management contract and you didn't think that it was, the consequence is pretty clear; the contract is void. And that is a huge risk. Everybody understands you really want to make sure you don't have a management contract, so you send it in to the NGIC and you get one of these letters that either says "This is a management contract and you need to go through the approval process," or "No, we agree with you. This is not a management contract." 


\section{DRAFT}

In contrast, on proprietary interest, neither the statutory provisions, nor the NIGC regulations - nor for that matter, Tribal gaming ordinances - explain the consequence if a contract violates the sole proprietary interest standard. So you get these letters from the NIGC that say "We think this violates the proprietary interest standard" but nobody knows what the consequence of that is. So, in addition to defining it I think somebody needs to say "What are the consequences?” This should appear either in the NIGC regs, or in the Tribal gaming ordinances.

Prof. Kevin K. Washburn: It seems in some respects that the NIGC might be concerned about usury -- that people are charging Tribes too much interest on their loans. A lot of this seems to focus on financing, but it seems like it is the NIGC and other federal approval requirements that create this process where people will only loan to the Tribes as long as they can get a really big cut of the revenues because there's so much risk involved. What do we do about that problem? And is that the concern? Is it the usury type problem?

Philip N. Hogen: Well if you have a situation where you've got a penniless Tribe, and they’ve got a place that might work and the developer comes along and says "This thing is going to make \$100 million and we'll give you \$10 million, take it or leave it,” the Tribe if they don't take the deal, they're still penniless; if they do take the deal they’ve got \$10 million but the other guy made $\$ 90$ million, and that's a bad fix to be in, and the market is not real flexible or transparent out there. I'm offended by the proposition that "Here comes this hot shot developer who's going to get rich more or less at the expense of the elders, the kids, the penniless tribe," so it would be nice to have that magic bullet that would prevent those situations. On the other hand, if that developer goes away, maybe nobody else is going to come along and the tribe gets nothing. So it's a challenge. It's a delicate balance and when you have the trustee hat to wear you've got to be extra careful the tribes aren't being taken advantage of, but you don't want to just scare away the investors or kill the goose that might lay the golden egg either.

Barry W. Brown: I agree, and in contrast to Vanya, my experience was always representing the Tribes on these deals, and I can tell you that some of the Tribal clients that I worked with were under a lot of pressure. By the time I got involved, they were being pressured very heavily by developers to sign a deal, and so I was hired to come in and basically peel that terms of the deal back and some of these were big time developers, and to that extent yeah, they were trying to take advantage of a Tribe that lacked the sophistication. They saw the numbers and said "You're going to make a lot of money and we're going to make a lot of money.” But as we parsed through the deal and looked at it and explained to them -- when you start putting real numbers on those percentages and explaining to the Tribe exactly the difference between paying on the gross and paying on the net and what that means in the real world, it changed. And so, I guess, to some extent, the growing sophistication of Indian Country is helping.

Again, not all Tribes are created equal and not all Tribes are able to afford top legal talent and financial talent at early stages within their development but I saw it happen first hand. Now, the flip side of that is "business is business," and, from a business standpoint, you are going to get the best deal as you possibly can. I mean, that's why you're doing it, but that I think addresses Chairman Hogen's comment. From the NIGC's standpoint, here we are; we were created for a reason, and the varying sophistication just blurs everything that much more. Some tribes may say "We don't need your help." In other instances I think there are good examples where the NIGC did step in and looked at some of these and said "The Tribe is totally getting ripped off here and whoever advised you was wrong." These deals don't have to be that lopsided, so hopefully things are changing. I guess my encouragement for those of you who are 


\section{DRAFT}

considering practicing Indian law, whether at a private law firm or within a Tribe, this type of education, combined with a business background and a finance background is desperately needed in Indian Country, and particularly for those who can sit down with Tribal membership. Within our own Tribe, the level of education even on the Council goes from professional degrees to eighth grade education, and so there is a big gap there, but I think going home and again, through the private sector or working directly for the Tribe, there is a tremendous need for both top legal talent and business/financial advice for tribes.

Prof. Kevin K. Washburn: I'm troubled again by this dynamic. The story seems to reflect that we have these well-funded investors who come in and steam roll over the tribe. Is that a valid concern? My sense is that a lot of tribes do an RFP, a Request for Proposals, and they get several different bidders. And then often they really are selecting from, the best deal -- the highest bidder or the lowest bidder, as the case might be. Should the tribal bidding process be a part of the question when the NIGC is reviewing contracts that the Tribe makes? Should that be part of the NIGC's review process, to see if the Tribe did use an open bidding type process? Or maybe another approach is to "means test" this? Should Tribes that are making more than \$100 million a year already be subject to NIGC regulatory oversight of their additional contracts? Obviously if they're making $\$ 100$ million a year or pick some arbitrary high figure, we know that they know how to do business, and they are sophisticated. Are there ways to help the poor Tribes, the penniless Tribes, the uneducated Tribes, or are their process mechanisms that might be more effective than the current regime which just funnels all the control to the NIGC?

Barry W. Brandon: I would keep as much away from the federal government as possible. I would reserve for the Tribe the ability to conduct business the way that they are comfortable conducting business because you are identifying a good business practice. My view always comes from respect for tribal sovereignty. Those people who are making that decision have been elected by their citizens. I don't want to step in and say, "I know better how you can get a better deal.” I'll defer to them, because in most instances, at least the Tribal governments that I represented, one of the things I always used to say is after exhausting all other options, the Tribe comes back and makes the right decision. They love to consider every other option before they come back to the ultimate decision.

Vanya S. Hogen: I would agree with that and add that the deals that I've been involved in usually involve an RFP process. In my experience, I haven't come across Tribes who are just willing to roll over. They're intensely negotiated deals, and the Tribes have sophisticated counsel. I mean the deal that I mentioned earlier where we ended up in arbitration in all those different forms was represented by Akin Gump, so it wasn't like they didn't have good, strong representation. But I don't think it is a good idea to send more control to the NIGC. For one thing, the agency seems to be somewhat overwhelmed. The management contract process takes such a long time because there is not adequate staff to make it happen much faster. And the " $R$ contract” review process is another story. Sometimes you can get a letter back in a week and sometimes it takes eight months. If you are a developer waiting to get a letter from the NIGC that your contract is okay and you can't get financing on the deal, the permanent financing can't happen until you get that letter. That can add months of delay where there could have been a casino operating. So more NIGC review is not the solution.

Prof. Kevin K. Washburn: Perhaps one of the things for which she should congratulate the NIGC is in its background investigation process. We haven't seen significant corruption and we haven’t seen very many bad actors involved in Indian gaming in the last 20 years. The Justice 


\section{DRAFT}

Department seems desperately interested in bringing criminal cases, but they seem to have difficulty finding significant cases of infiltration by the criminal element. This suggests to me that the background investigation, the suitability determinations of individuals that NIGC is doing is very successful. NIGC and the tribal gaming commissions must have been successful in weeding out the bad actors for the Tribes.

On the other hand, the reviews are much more mixed as to whether the NIGC's economic regulatory mechanisms have been successful. Chairman Hogen says that Indian gaming has been very successful, and so we don't want to tinker with it, but maybe it would have been twice or three times as successful if NIGC had not been scuttling some of the deals. It's possible; we just don't know.

But there have been very few problems with corruption and criminal activity involving gaming. So what I had suggested to McCain was, I thought that we should increase the background investigation work that the NIGC does, the corruption prevention work, make sure Tribal leaders are not lining their pockets with secret deals with developers or something like that, but not so much to regulate the business decisions of Tribes; that maybe Tribes should be left to make their own business decisions without too much oversight. Thoughts?

Philip N. Hogen: Well, I think there is merit in considering that approach. One of the things that will disqualify someone involved in a management contract is if they unreasonably interfere with the political life of the Tribe. I don't know that such influences have always been detected. I think there may have been instances where the developer came in early and influenced who was going to sit on that Tribal Council and so forth. And you may have a small Tribe with no resources, maybe a couple of federal programs, but no full-time employees at the Tribal governmental level. Yet, they are supposed to be sitting down to work on a \$500 million deal, so they get some of the money up front. If that has happened, it may be pretty hard to just ignore that pressure and say "This guy, this company, this person, is not the one we want to keep going with. Three months, a year down the road, it may be difficult to go out with a new request for proposals and throw out the people who brought us here. As I mentioned when I started talking, you also get situations in which that developer will find a champion there within the Tribe. If somebody says "well, this is not the best deal," suddenly it becomes personal and it creates tribal in-fighting.

The amendment that eventually was before the Senate Indian Affairs Committee Senate Bill S.2078 that was at a hearing where Professor Washburn and I testified, would have said that the NIGC's job is not just to review management contracts, but to review all gaming related contracts and to do it in a great hurry. The Tribal gaming industry was justifiably concerned that reviewing even more contracts would just slow us down immensely and create a bottleneck. They wondered: "Are they going to have to look at every contract when we want to buy a slot machine?" It probably wasn't workable, but it attempted to create scheme that would allow more background investigations on a broader range of people. So I think that it probably can be fine-tuned. I don't think that the approach that was eventually embodied in that bill is the right one, but maybe less business review and more background investigation would be a better approach.

Barry W. Brandon: Being an alum of the NIGC, I certainly appreciate the role and responsibility. I think it is a necessary agency. Based upon some of the things that we've talked about to here, and knowing again that one size doesn't fit all, I think that a lot of Tribes need very little from the NIGC. I think the fact that all external measurements would show that they are well-run, well-operated, well-managed. I think that really what we are talking about is the smaller, less sophisticated operations which were much more rife for shenanigans in terms of 


\section{DRAFT}

money kind of squirting out the back door because of the lack of control. So that's where I see the NIGC playing a much more prominent and influential role kind of along the lines of the training and education and those types of things, based upon the assumption that Tribes want to get it right.

Tribes want to be well-regulated. Their chief source of income is at risk. That is one of the reasons you haven't found any of these bad actors. At least for the Tribes I worked for, nobody cared more about the image and the integrity of that organization than the Tribe itself. It was very, very important in terms of their image. Most of them have their names on these establishments, so it's very important to make sure that they're well-run and well-operated and I think that's helped control any bad influences. But I think with the background, the training, the education as well as even as we've talked today, even the opportunity to engage with Tribal counsels about various issues that they're going to face as counselors with respect to financing and developers and offering up that type of information to them in a generic format just so that we continue the learning curve, because this works not only for gaming, but just for business in general too.

Prof. Kevin K. Washburn: Thank you for participating. 